\title{
Analysis of Difficulties in Learning Physical Education in Children with mild Developmental Disabilities in SLB Binjai City
}

\author{
Anggun Lestari Tanjung \\ Physical Education \\ Medan State University \\ Medan, North Sumatra, Indonesia \\ Anggun_oss@yahoo.com
}

\author{
Albadi Sinulingga \\ Physical Education \\ Medan State University \\ Medan, North Sumatra, Indonesia
}

\author{
Nurhayati Simatupang \\ Physical Education \\ Medan State University \\ Medan, North Sumatra, Indonesia
}

\begin{abstract}
This research approach is carried out qualitatively, meaning that research procedures produce descriptive data in the form of words from people or observed behavior. The subjects of the study were Physical Education teachers in SLB Binjai City and several Tunagrahita class students. This is because Physical Education teachers and students are people who have enough information as the main informants. The main informant is a subject who experiences and supports the implementation of the Physical Education learning process at SLB in Binjai City. Then supported by the subject of the principal and parents. So that the number of research subjects is 8 people. As for the research objects in this paper include the study of difficulties in learning physical education in mentally disabled children. The study was conducted at locations in SLB Binjai and SDLBN 027701 Binjai so that the resource persons were easier to conduct interviews and observations. the focus of the problem in this study is on the difficulties that occur in learning physical education in mild retarded children in SLB Binjai City. This study aims to obtain a comprehensive picture of the process of implementing physical education in mild retarded children in Binjai City such as: 1) To describe the analysis of the implementation of physical education in mild retarded children in Binjai City. 2) To describe the difficulties of implementing physical education can occur in mild retarded children in the City of Binjai.
\end{abstract}

Keywords- Tuna Grahita, Physical Education, Adaptive Physical Education

\section{INTRODUCTION}

Education as an important thing should not be ignored because education aims to equip students in preparing their future. Therefore, a meaningful learning process determines the achievement of quality education. Students need to get adequate guidance, encouragement, and opportunities in learning and learning the things they need in their lives later. Education is a basic need of every human being to ensure his life to be more dignified. According, that the state has an obligation to provide quality educational services to each of its citizens without exception including individuals who have differences in ability (disability) as stipulated in the 1945 Constitution article 31 (1).

Physical education (Physical Education) is an integral part of overall education that is able to develop children or individuals as a whole in the sense of covering physical, intellectual (interpretive ability), emotional and moral spiritual aspects which in the learning process prioritizes physical activities and habitualization of healthy lifestyles. Physical education is a learning process through physical activities that is designed to improve physical fitness, develop motor skills, healthy and active life knowledge and behavior, sportsmanship, and emotional intelligence. The learning environment is carefully regulated to promote the growth and development of all students, psychomotor, cognitive, and affective domains. The learning experiences presented will help students to understand why humans move and how to do safe, effective and efficient movements.

Physical education is characterized by a process of learning sports movements. Learning movement skills is one part of physical education learning in schools to which responsibility is imposed so that children have adequate mobility skills. Motion skills are abilities possessed by students as a provision to live everyday life.

The Physical Education Objectives stated by the Ministry of National Education (2003: 6) are:

1) Laying a strong foundation of character through internalizing values in physical education; (2) Building a strong foundation of personality, peaceful attitudes, social attitudes and tolerance in the context of cultural, ethnic and religious diversity; (3) Developing sportsmanship, honesty, discipline, responsibility, cooperation, self-confidence and physical activity; (4) Developing self-management skills in developing efforts to maintain physical fitness and healthy lifestyles through various physical activities; (5) Able to fill free time with physical activities that are recreational and; (6) Fostering critical thinking skills through physical education tasks. 
Physical education is taught to children with special needs as well. Children with special needs are children who need special handling because of developmental disorders and abnormalities experienced by children. Related to the term disability, children with special needs are children who have limitations in one or several abilities both physical in nature such as visual impairment and hearing impairment, as well as psychological characteristics such as autism and ADHD.

Special disorders of the physical or mental in children with special needs who have developmental impairments (mentally disabled) require special education services in accordance with the Law of the Republic of Indonesia concerning the National Education System No. 2 of 1989 (in article 11 paragraph 4 and article 38) and reaffirmed in the RI Law on National Education System No. 20 of 2003 in article 3 paragraph 1 that: special education is education for students who have difficulty in following the learning process because of physical, emotional, mental, social and / or potential for intelligence and special talents.

The special education referred to in the RI Law above is to consider that each student is different in their level of learning ability achievement. Children who are mentally disabled desire a decent life, wanting harmonious growth and development. Therefore they also need education and guidance in order to become mature humans and become citizens who can participate in the development of their nation and state. Education for children with special needs requires a separate service pattern, especially for children with functional developmental impairments (children with developmental impairment), developmental impairment refers to a certain condition with the presence of intelligence and adaptive functions, by showing various problems with cases different cases [2]. Education for children with disabilities can be done in families, communities (non-formal), and in schools (formal). Formal education for children with disabilities is usually provided by foundations or special schools (SLB). Every SLB has an educational curriculum program in rehabilitating, training and educating children with disabilities, including physical education programs for children with disabilities (adaptive physical education).

Educational goals for mentally retarded children according to [3] are, as follows:

1) The goal of mild mentally retarded children's education is so that children can take care and foster themselves, and can get along in society.

2) The aim of mentally retarded children's education is that children can take care of themselves; like eating and drinking, and being able to get along with family members and neighbors.

3) The goal of a mentally retarded child's education is heavy and very heavy is to be able to take care of themselves as simple as giving signs or words when wanting something, such as eating and pooping.

In carrying out the educational goals for mentally disabled children is not as easy as when carrying out the education process for normal children in general. As in the focus of this study where, researchers take the problem of physical education learning in mild retarded children. Physically mentally retarded children are not different from normal children in general but psychologically different. But in learning many are not able to run it properly.

According to 2009 UNESCO data, Indonesia's ranking in the organization of education for ABK continues to decline. In 2007, Indonesia ranked 58th out of 130 countries, while in 2008 it fell to 63rd out of 130 countries. In 2009, Indonesia's ranking even dropped to 71 st out of 129 countries. All of the above is due to the number of ABK in Indonesia that are still few registered in schools

The data above, supported by observational data conducted at SDLBN 027701 Binjai and SLB Binjai, where the two Extraordinary Schools in Binjai use the 2013 curriculum. And learning is usually adjusted to the classification of each person. In both schools there were 53 students with mild disabilities in SDLBN 027701 and 67 students with mild disabilities in SLB Negeri Binjai.

In the observation of learning in the two schools that physical education learning is carried out at hours that have been set in such a way, it's just that the implementation of adaptive physical education learning is still carried out mixed with other children with disabilities such as mild mental disability, autism and Down syndrome both mild and mild whereas each child their needs cannot be equated because of the different characteristics of weaknesses and strengths of children with special needs.

Then in the observation of learning where the teacher tries to deliver the material, but the child's ability to respond to each command is still limited. What happens in the field when the teacher instructs gymnastics, there are still many students who do not respond to the teacher's command so that there are students who do and some do not do. Difficult to achieve physical education learning because of this.

Then what happens in the field is that the context of adaptive physical education should be different from the physical education in public schools, unfortunately the physical education teacher implements learning not based on the DAP concept which arranges a game based on the child's needs. So that learning is more often carried out like learning in normal children in general. So that the values and aspects of learning adaptive physical education are difficult to achieve, it should be through physical education that can improve the abilities of children with special needs both in terms of motor and cognitive and affective aspects of these students.

Based on these learning observations, researchers are interested in conducting research related to the difficulties in physical education learning activities for special needs children with special mental disabilities in SLB Negeri Binjai. The research that will be carried out is entitled "Analysis of Difficulties in Learning Physical Education in Children with Light Developmental Disabilities in SLB Binjai City".

This problem is important to be investigated because if it is ignored, the need for adaptive physical education in children with special needs, especially in mild mental retardation children will be less good and will also have an impact on the physical health of the child. Researchers take the qualifications 
of children with mild mental retardation because according to researchers mild retarded children still look like normal children so many things are able to be developed to achieve the learning goals of mild retarded children in physical education learning. Indeed, basically, as a teacher does not require the child to be able to do many things as in normal children. But it would be nice if the affective, cognitive and psychomotor needs are not wrong in its achievement. This makes researchers want to examine more deeply about the implementation of adaptive physical education in mentally retarded children

\section{METHODS}

Conducted qualitatively, meaning that research procedures produce descriptive data in the form of words from people or observed behavior [4]. This approach is directed at the cultural and individual backgrounds that are used as informants / informants of this research holistically (whole). Basically, according to some experts, there are several methods developed in qualitative research, including; case studies, phenomenology, grounded theory, ethnometodology, ethnography, biography, clinical research and historical social sciences.

This qualitative research design is a case study, a case study is an approach to study, explain, or interpret a case in its context naturally without any intervention from outside parties [5]. Case studies are also in-depth research on social units whose results are a complete and well-organized picture of these units.

The reason researchers use case studies is because this research examines existing cases so researchers only study existing cases. The choice of a qualitative approach itself is based on the following reasons. First, the result data in the form of difficulties and implementation of physical education learning. The data in this study are more words, stories or narratives than numbers. Words and stories play a dominant role in detesis rather than statistical figures. Second, the purpose of this study is not to assess, measure or evaluate the difficulty of implementing physical education learning for mentally disabled children at SLB Binjai City.

\section{DISCUSSION}

The object of research is the subject matter that wants to be investigated to get data more directed. The research objects in this paper include the study of difficulties in learning physical education in mentally disabled children.

The study was conducted at locations in SLB Binjai and SDLBN 027701 Binjai so that the resource persons were easier to conduct interviews and observations. The entire series of research processes is estimated to have taken \pm 6 months from proposal preparation and is divided into three main stages, namely the research preparation stage, the operational stage, and the report preparation stage.

\section{a. Research Preparation Phase}

This phase is planned to run for two months (May 2019 / July 2018). Included in this stage is the process of preparing a research design that includes an outline of the method, namely the determination of the focus of the problem, the study of literature, the suitability of the paradigm with the focus of the problem, engineering design, instrumentation and data validation, and the design of data analysis procedures. This stage leads to the fulfillment of research administrative legal requirements in the form of licensing matters with the relevant authorities.

The process of this research begins with the interest of researchers to find out the analysis of the difficulties in implementing physical education learning in SLB Binjai City. During the initial thesis process, the researcher still often discussed and approached the speakers so that they were more familiar. To facilitate the course of research, researchers try to approach the speakers, this is done so that the relationship between researchers and speakers more harmonious.

\section{b. Operational Stage}

This phase is planned to take one month (July 2019 to August 2019). This stage includes data collection, research findings, data verification and discussion of research findings. At this stage the researchers photographed the background of the study in accordance with the data collection methodology prepared. The two main work agendas of this stage are data collection, and at the same time data analysis is carried out. Together with the research supervisor at this stage, a final report on the research results was prepared. This was taken apart from the technical consideration of "utilizing time as efficiently as possible" also because researchers used the flow and interactive model as recommended.

\section{c. Report Preparation Phase}

Based on the results of data analysis and consultation of the draft final report with the study report report supervisor written. The writing and editing of the final manuscript was carried out during the middle of September 2019. The main activity besides preparing the report was the final evaluation of the study results.

\section{REFERENCES}

[1] Agus Salim, 2001. Teori dan Paradigma Penelitian Sosial. Yogyakarta: Tiara Wacana.

[2] Bandi Delphie. 2006. Pembelajaran Anak Tunagrahita. Bandung: Refika Aditama.

[3] Dinie Ratri Desiningrum. 2016. Psikologi Anak Berkebutuhan Khusus. Yogyakarta: Psikosain.

[4] Moleong, L.J. 2004. Metodologi Penelitian Kualitatif Edisi Revisi. Bandung: Rosdakarya.

[5] Syaiful Bahri Djamarah. 2011. Psikologi Belajar. Jakarta: PT Rineka Cipta. 